\title{
INQUIRY INTO HIGH SCHOOL STUDENTS' UTILITY FUNCTION
}

\author{
Julius Janáček, Dan Št’astný
}

\section{Introduction}

The economic science has for centuries anchored its endeavor to understand decisionmaking patterns of people in explicit or implicit assumptions of utility maximization. And yet, for most of that time the utility remained an empty box, devoid of any content. The term utility was a scholarly short-hand for whatever people want to achieve and remained vague for a reason: in recognition of the subjective nature of what human preference it was designed to accommodate just about anything, and it was after all considered none of economists' business to speculate about its precise content.

In the last fifty years or so, this has thoroughly changed through a gradual marriage of economics to psychology. The most explicit phase of this process started with the happiness research, a research program inquiring into what exactly it is that makes people happy or, more generally, satisfied with life. Within the decades of its existence, it has had a rich history and its complexity provides almost endless grounds for replication and testing.

An important aspect of why investigating the shapes of utility functions (i.e. the factors of happiness) is valuable is that humans continuously tend to underestimate or overestimate certain well-being factors. As a consequence, they make biased decisions and their life may turn less enjoyable than it could be. An example of this phenomenon is the fact that people who believe that financial success is the main determinant of their quality of life report lower life satisfaction and worse health (Diener, Gohm, Suh, \& Oishi, 2000; Kasser \& Ryan, 2001; Kasser, 2002). Being aware of one's biases may assist individuals in introspection and reevaluation of their priorities.

Similarly, understanding the utility content of individuals or their groups may improve upon efficiency of policies in both private and public sector. For example, the limited efficiency of monetary incentives and understanding people's real motivation for job performance has proved crucial in human resource management in business (see e.g. Becchetti, Castriota, \& Tortia, 2013; Broedling, 1977; Kasser \& Ryan, 2001; Murdock, 2002), non-profits (e.g. Bissell, 2012; van Schie, Güntert, \& Wehner, 2014) and public policy areas as public service (e.g. Delfgaauw \& Dur, 2008; Lambright, 2009; Georgellis, lossa, \& Tabvuma, 2011), education (e.g. Curran, 2018; Levitt, List, Neckermann, \& Sadoff, 2012), or health care (e.g. MadridejosMora, Amado-Guirado, \& Pérez-Rodríguez, 2004; Phipps-Taylor \& Shortell, 2016). The general importance of studying life satisfaction for public policy design is pointed out by Diener and Seligman (2004).

Despite its limited scope (teenage students of secondary level institutions), we believe that our research may contribute precisely to that end: it is potentially useful in areas ranging from macro-level policies to parental practices to students' own mindfulness. By providing a better understanding of values attached to different aspects of life, we may encourage using better means to promote life satisfaction, or pursuing other objectives by means that are more compatible with life satisfaction (and hence more effective).

In this study, we present results of a survey among high school students and models estimating the influence of a wide variety of factors on their life satisfaction. With no particular hypotheses in mind, we were broadly interested in isolating factors that do seem to make a difference to life satisfaction (and finding out how much) and factors that do not. In short, we attempt to fill in the content of the utility function of high school students. (There may be some practical and philosophical differences between happiness and life satisfaction, but 
we join the tradition of using these two terms synonymously. In the survey itself, we avoided confusion by eschewing the term happiness altogether.)

The first section puts our research in context of previous studies. Section 2 describes the dataset, and section 3 our models determining life satisfaction. Section 4 discusses noteworthy findings, section 5 compares our results to conclusions of previous studies dedicated to high school students, and the last section concludes.

\section{Literature Review}

While life satisfaction or happiness has always been implied in economic theorizing in one way or another, it became an explicit focal point of economists in the 1970s when Easterlin (1974) and Scitovsky (1976) started to apply a scientific and statistical approach to investigate different factors influencing happiness and life satisfaction. The publicity of happiness research has risen dramatically in the last twenty years. Many economists have started to integrate the concept of life satisfaction into both microeconomic and macroeconomic research (see e.g. Frey, 2008; Diener \& Chan, 2011; Case \& Deaton, 2016). This development was accentuated by two Nobel prizes for economics being awarded to authors involved in happiness research. It has turned by now into a field of its own with its own journal - the Journal of Happiness Studies. For a general overview of the happiness research and its results see e.g. Bruni (2007).

The various shades of happiness are distinguished e.g. by Nettle (2006) into 3 types:

1. Feelings of pleasure and good mood. In psychology, this type of happiness is often referred to as positive and negative affect.

2. Complex long-term contentment with life referred to as "life satisfaction".

3. Being able to realize one's potential and fulfill their life purpose.

Lucas et al. (1996) show that pleasant (positive) affect and life satisfaction are different constructs and that they should be separated. To make the matter more complicated, Kahneman and Deaton (2010) investigate the issue further and highlight the distinction between the general evaluation of life and emotional wellbeing. They argue that these two concepts should be distinguished as there are significant differences in the ways they interact with other factors. They show, for example, that higher income has a positive effect on the evaluation of life (on this point see also e.g. Gardner \& Oswald, 2001; or Stevenson \& Wolfers, 2013), but does not influence emotional well-being in a significant way.

Many of the factors inquired about in this study were subject of past research. Life satisfaction has been shown to vary with quality of housing (e.g. Kozma \& Stones, 1983; Cattaneo, Galiani, Gertler, Martinez, \& Titiunik, 2009), commuting time (e.g. Stutzer \& Frey, 2008), health (in both causal directions, e.g. Diener \& Chan, 2011; Lambert et al., 2014; or Kozma \& Stones, 1983) or personal relationships (e.g. Holder \& Coleman, 2009; Kalvans \& Ignatjeva, 2013).

Regarding our focus specifically on teen students, the past research is sparser. The recent ones include expectedly those located in the US (Flynn \& Macleod, 2015; Harmening \& Jacob, 2015), complemented by studies focusing on rather exotic locations: Turkey (Demirbatir, 2015), Iran (Zarei, 2013; Abedini \& Majareh, 2015), India (Peltzer \& Pengpid, 2013), New Zealand (Lambert et al., 2014) and Chile (Morales et al., 2015).

Despite the size and breadth of happiness research, there are still many unresolved problems in this field. Perhaps most disappointingly, the question of causality is still not settled in many areas. For example, there is a positive relationship between marriage and life satisfaction (Coombs, 1991; Stack \& Eshleman, 1998; Diener et al., 2000). But does marrying make people happy or do happy people get married? It is believed that the effect goes both ways (Mastekaasa, 1992; Stutzer \& Frey, 2006) or to marriage effects (social causation but it has so far proved impossible to determine further details.

There are also many questions concerning the differences between countries and cultures. Although Helliwell (2006) has shown in his large research on happiness that demographic, economic, and political factors on happiness are more or less the same regardless of concrete personality differences, it cannot be said about the differences between different social backgrounds (Uchida, Norasakkunkit, \& Kitayama, 2004). For example, Deaton (2008) has demonstrated that there is a sharp difference in the way life satisfaction develops with age in different countries. While the 
progress is generally u-shaped in Western Europe with the minimum around the age of 50, people from Eastern Europe experience a slow decline in the level of happiness throughout their whole life. The knowledge that there are such distinct differences between different social groups opens a whole new area of potential research.

\section{Survey}

In line with the typical happiness research, we use our own survey data and build models explaining the self-assessed degree of life satisfaction through a host of explanatory variables. In this section, we will first describe the data collection and coding and then focus on some descriptive statistics.

\subsection{Survey Data}

The data used in this study was collected by a series of surveys among students of all grades in institutions of secondary education in northern region of the Czech Republic in the Spring of 2017. These institutions ranged from universal gymnasiums (grammar schools) to various vocational schools (business, medical, trade).

The surveys were administered during regular classes by the respective teachers, who were provided manuals and support by research assistants. Anonymous paper questionnaires were distributed to all students during a regular class and collected afterwards. The questionnaire contained dozens of questions inquiring about different domains of students' life that can be broadly grouped into happiness, housing, health and lifestyle, economic and personal factors. (This aggregation does not necessarily reflect the way (or even order) in which the questions were asked in the survey questionnaire, which bundled questions more by type (scale, binary) rather than by domain.) For the key happiness metric we ask a qualityof-life question, "How do you evaluate the quality of your current life?", with a traditional

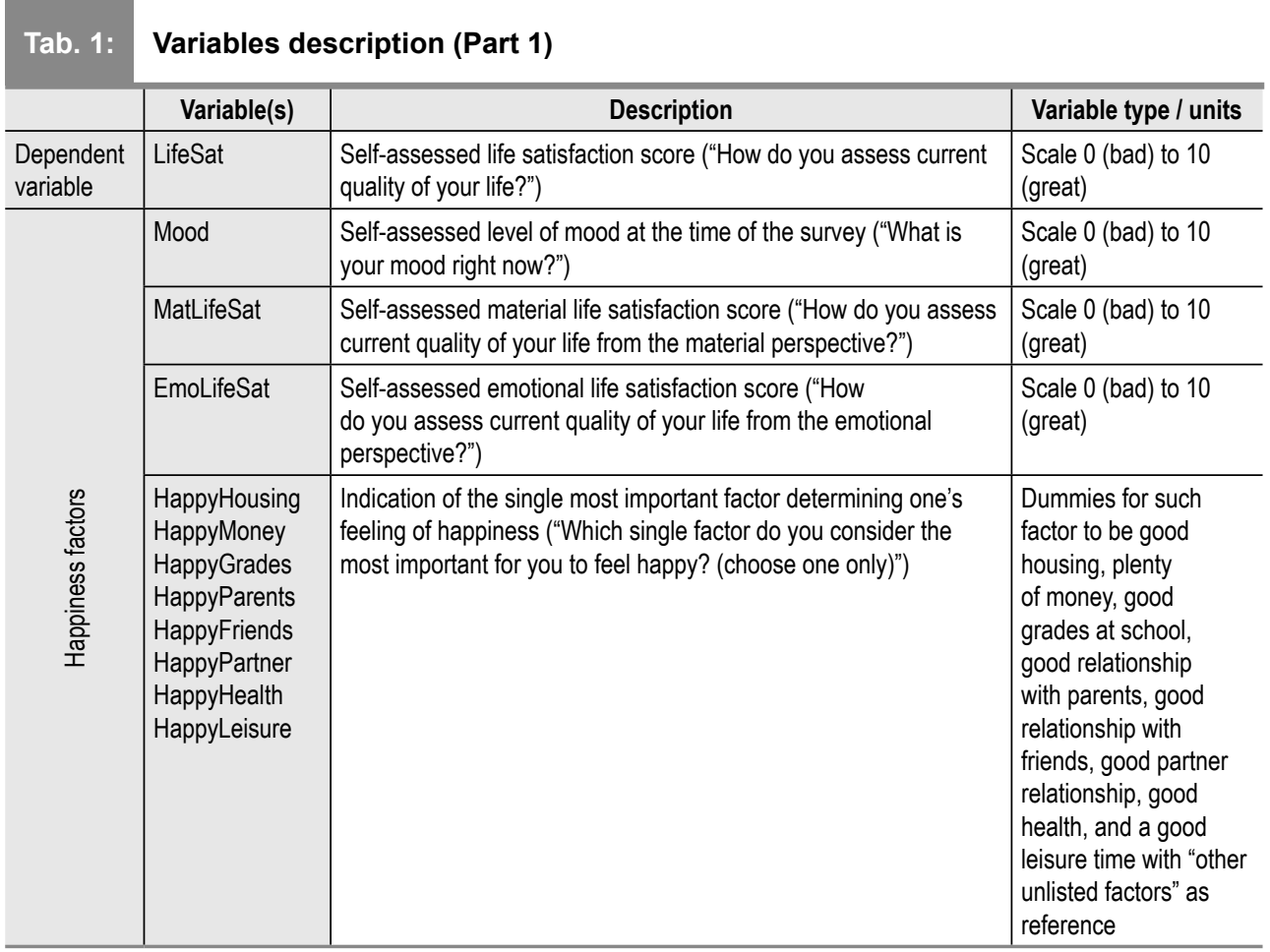


Tab. 1: Variables description (Part 2)

\begin{tabular}{|c|c|c|c|}
\hline & Variable(s) & Description & Variable type / units \\
\hline \multirow{4}{*}{ 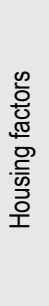 } & Population & $\begin{array}{l}\text { Size of the settlement one lives in ("What is the approximate } \\
\text { population of the place you live?") }\end{array}$ & Integer \\
\hline & Homeowner & $\begin{array}{l}\text { Indication of being a homeowner ("Do you or your family live } \\
\text { in your own house?") }\end{array}$ & Dummy (1=yes, $0=$ no) \\
\hline & CommuteTime & $\begin{array}{l}\text { Number of minutes it takes to commute to school on average } \\
\text { (one-way) }\end{array}$ & Integer \\
\hline & LiveWParents & $\begin{array}{l}\text { Indication of living with one's parents ("Do you live with your } \\
\text { parents?") }\end{array}$ & Dummy (1=yes, $0=$ no) \\
\hline \multirow{13}{*}{ 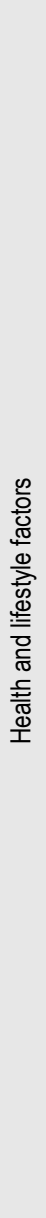 } & PHealth & Self-assessed level of physical health ("I am physically healthy.") & $\begin{array}{l}\text { Scale } 0 \text { (disagreement) } \\
\text { to } 10 \text { (agreement) } \\
\end{array}$ \\
\hline & MHealth & Self-assessed level of mental health ("I am mentally healthy.") & Scale $0-10$ \\
\hline & Cigarettes & Number of cigarettes smoked daily on average & Integer \\
\hline & Cannabis & $\begin{array}{l}\text { Indication of being a cannabis use ("Do you smoke or use } \\
\text { marihuana regularly?") }\end{array}$ & Dummy (1=yes, $0=$ no) \\
\hline & Alcohol & $\begin{array}{l}\text { Quantity of alcohol consumed weekly ("How many units of alcohol } \\
\text { do you drink per week on average ( } 1 \text { unit = } 0.5 \text { liter beer, } 0.2 \text { liter } \\
\text { wine, } 1 \text { shot of liquor)?") }\end{array}$ & Integer \\
\hline & Breakfast & $\begin{array}{l}\text { Indication of having breakfast regularly ("I regularly have } \\
\text { breakfast.") }\end{array}$ & Scale $0-10$ \\
\hline & $\begin{array}{l}\text { Vegetarian } \\
\text { Vegan }\end{array}$ & Indication of diet habits & $\begin{array}{l}\text { Dummies for } \\
\text { vegetarians and } \\
\text { vegans with omnivores } \\
\text { as reference }\end{array}$ \\
\hline & Sport & $\begin{array}{l}\text { Number of hours per week spent doing sports on average ("How } \\
\text { many hours per week do you spend doing some sport activity } \\
\text { on average?") }\end{array}$ & Integer \\
\hline & TV & $\begin{array}{l}\text { Number of hours per week spent watching TV on average ("How } \\
\text { many hours per week do you spend watching TV on average?") }\end{array}$ & Integer \\
\hline & Friends & $\begin{array}{l}\text { The number of hours spent weekly with friends outside of } \\
\text { classroom ("How many hours per week do you spend with your } \\
\text { friends outside of classroom on average?") }\end{array}$ & Integer \\
\hline & SocialMedia & $\begin{array}{l}\text { The number of hours spent weekly on social media ("How many } \\
\text { hours per week do you spend on social media (Facebook etc.) } \\
\text { on average?") }\end{array}$ & Integer \\
\hline & Reading & $\begin{array}{l}\text { The number of hours spent weekly reading ("How many hours per } \\
\text { week do you spend reading on average?") }\end{array}$ & Integer \\
\hline & Art & $\begin{array}{l}\text { The number of hours spent weekly on artistic or creative activities } \\
\text { ("How many hours per week do you devote to artistic activities } \\
\text { (musical instruments, drawing, dancing, pottery, crafting etc.) } \\
\text { on average?") }\end{array}$ & Integer \\
\hline
\end{tabular}




\section{Ekonomie}

Tab. 1: Variables description (Part 3)

\begin{tabular}{|c|c|c|c|}
\hline & Variable(s) & Description & Variable type / units \\
\hline \multirow{5}{*}{ 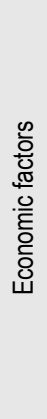 } & Finance & $\begin{array}{l}\text { Self-assessed level of one's financial situation ("I consider my } \\
\text { financial situation as...") }\end{array}$ & $\begin{array}{l}\text { Scale }-5 \text { (wholly } \\
\text { negative) to } 5 \text { (wholly } \\
\text { positive) }\end{array}$ \\
\hline & Allowance & $\begin{array}{l}\text { Amount of money received as allowance per month on average } \\
\text { ("What is your monthly allowance on average?") }\end{array}$ & Integer \\
\hline & Earnings & $\begin{array}{l}\text { Amount of money earned by working per month on average } \\
\text { in CZK ("What are your monthly job earnings on average?") }\end{array}$ & Integer \\
\hline & OwnBusiness & $\begin{array}{l}\text { Indication of having one's own business now ("Do you have your } \\
\text { own business now?") }\end{array}$ & Dummy (1=yes, $0=$ no) \\
\hline & ParentsBusiness & $\begin{array}{l}\text { Indication of one's parents having their business ("Do any of your } \\
\text { parents have their own business?") }\end{array}$ & Dummy (1=yes, $0=$ no) \\
\hline \multirow{15}{*}{ 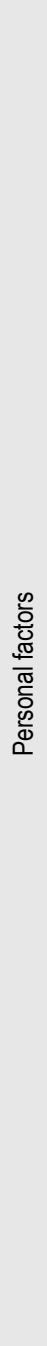 } & Grades & $\begin{array}{l}\text { Self-assessed level of relative academic achievements } \\
\text { ("How do you view your academic achievements?") }\end{array}$ & $\begin{array}{l}\text { Five ordered classes: } \\
1=" A \text { mong the worst" } \\
2=" B e l o w \text { average" } \\
3=" A \text { verage" } \\
4=" A b o v e \text { average" } \\
5=" A m o n g \text { the best" }\end{array}$ \\
\hline & Partner & $\begin{array}{l}\text { Indication of having a steady relationship ("Do you have } \\
\text { a partner?") }\end{array}$ & Dummy (1=yes, $0=$ no) \\
\hline & RelParents & $\begin{array}{l}\text { Self-assessed quality of the mutual relationship with one's parents } \\
\text { ("My relationship with my parents (mutual) is...") }\end{array}$ & $\begin{array}{l}\text { Scale }-5 \text { (wholly } \\
\text { negative) to } 5 \text { (wholly } \\
\text { positive) }\end{array}$ \\
\hline & RelNationality & $\begin{array}{l}\text { Self-assessed quality of relationship to one's nationality } \\
\text { ("My relationship to my nationality is..."). }\end{array}$ & Scale -5 to 5 \\
\hline & Entrepreneur & $\begin{array}{l}\text { Self-assessed degree of intention to have one's own business } \\
\text { in the future ("I plan to have my own business in the future.") }\end{array}$ & Scale $0-10$ \\
\hline & Selfcare & $\begin{array}{l}\text { Self-assessed capability of taking care of oneself ("I am and will be } \\
\text { able to support, and take care of, myself.") }\end{array}$ & Scale $0-10$ \\
\hline & LifeControl & $\begin{array}{l}\text { Self-assessed degree of being in charge of one's life ("I have } \\
\text { a direct control over what is happens in my life.") }\end{array}$ & Scale $0-10$ \\
\hline & FeelUnsafe & Self-assessed feeling of insecurity ("In my life I do not feel safe.") & Scale $0-10$ \\
\hline & FeelUnfree & $\begin{array}{l}\text { Self-assessed feeling of not being free ("In my life I do not feel } \\
\text { free.") }\end{array}$ & Scale $0-10$ \\
\hline & Religious & $\begin{array}{l}\text { Self-assessed degree of one's religiosity ("I am a believer } \\
\text { or a spiritually-minded person.") }\end{array}$ & Scale $0-10$ \\
\hline & Beauty & $\begin{array}{l}\text { Self-assessed degree of being able to perceive beauty } \\
\text { ("I can perceive beauty in things around me.") }\end{array}$ & Scale $0-10$ \\
\hline & Gifts & $\begin{array}{l}\text { Amount of money spent yearly on gifts to other people on average } \\
\text { ("What are your yearly expenditures on gifts to other people } \\
\text { on average?") }\end{array}$ & Integer \\
\hline & Helping & $\begin{array}{l}\text { Self-assessed degree of one's willingness to help others } \\
\text { ("I am happy to help people.") }\end{array}$ & Scale $0-10$ \\
\hline & Needed & $\begin{array}{l}\text { Self-assessed feeling of being needed by others ("I feel like other } \\
\text { people need me.") }\end{array}$ & Scale $0-10$ \\
\hline & Nature & $\begin{array}{l}\text { Self-assessed degree of importance of being in touch with nature } \\
\text { ("Being in touch with nature is important to me.") }\end{array}$ & Scale $0-10$ \\
\hline
\end{tabular}




\section{Tab. 1: Variables description (Part 4)}

\begin{tabular}{|c|c|c|c|}
\hline & Variable(s) & Description & Variable type / units \\
\hline \multirow{9}{*}{ 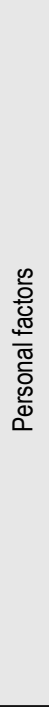 } & Recycle & $\begin{array}{l}\text { Indication of whether one recycles waste ("Do you recycle } \\
\text { waste?") }\end{array}$ & Dummy $(1=y e s, 0=$ no) \\
\hline & Serious & $\begin{array}{l}\text { Self-assessed degree of being serious or staid ("I have a hard time } \\
\text { making fun out of things.") }\end{array}$ & Scale $0-10$ \\
\hline & Indecisive & $\begin{array}{l}\text { Self-assessed degree of being indecisive ("I have a hard time } \\
\text { making decisions.") }\end{array}$ & Scale $0-10$ \\
\hline & Attractive & $\begin{array}{l}\text { Self-assessed degree of one's attractiveness ("I consider my } \\
\text { appearance attractive.") }\end{array}$ & Scale $0-10$ \\
\hline & MeaningfulLife & $\begin{array}{l}\text { Self-assessed feeling of having a meaningful life ("My life has } \\
\text { a meaning.") }\end{array}$ & Scale $0-10$ \\
\hline & SelfSatisfaction & $\begin{array}{l}\text { Self-assessed degree of satisfaction with oneself ("I am satisfied } \\
\text { with the way I am.") }\end{array}$ & Scale $0-10$ \\
\hline & SelfReward & $\begin{array}{l}\text { Indication of indulging in rewards for one's own achievements } \\
\text { ("Do you reward yourself for successes you achieve?") }\end{array}$ & Dummy $(1=y e s, 0=$ no $)$ \\
\hline & OpenToChange & Self-assessed degree of one's flexibility ("I am open to changes.") & Scale $0-10$ \\
\hline & Discriminated & $\begin{array}{l}\text { Self-assessed feeling of being discriminated ("I feel I am being } \\
\text { discriminated or humiliated in my life (on grounds of race, sexual } \\
\text { orientation etc.).") }\end{array}$ & Scale $0-10$ \\
\hline \multirow{3}{*}{$\begin{array}{l}\frac{\infty}{0} \\
\text { 일 } \\
\text { Oे }\end{array}$} & Gender & Respondent's gender & $\begin{array}{l}\text { Dummy } \\
(1=\text { female, } 0=\text { male })\end{array}$ \\
\hline & Age & Respondent's age & Integer \\
\hline & School1..10 & Identification of school attended by respondent & $\begin{array}{l}\text { Dummies for schools } \\
1 \text { to } 10 \text { with } 11^{\text {th }} \text { school } \\
\text { as a reference }\end{array}$ \\
\hline
\end{tabular}

Source: own

choice of an answer on a scale from 0 (lowest quality) to 10 (highest quality) -identical metric used in many other studies (e.g. Helliwell, Layard, \& Sachs, 2015).

Tab. 1 presents data variables derived from the questionnaire questions, their coding, units and ranges.

The first group of variables bundles together those that are or may be in one way or another directly linked to life satisfaction (or did not fit other groups). We ask about students' mood (capturing immediate feeling) to see how much it affects the life satisfaction as a long-run concept. We ask about two different dimensions of life satisfaction to check different treatment of each by students. Then there is a special set of dummy variables designed to find out the first aspect students associate with being happy.

Most questions in other groups are common to appear in a life-satisfaction survey. Some sets of questions attempt to dive deeper then usual: we ask about physical and mental dimensions of health (rather than health in general), differentiate between allowance and earnings (rather than income in general), or try to tap into the contrast between security and freedom (FeelUnsafe vs. FeelUnfree). In personal factors, our survey was particularly generous as regards the number of questions, ranging from academic performance to relations to personal traits to some more abstract ones (like ability to perceive beauty).

\subsection{Descriptive Statistics}

Tab. 2 presents the summary statistics for the whole sample of 1,414 participants of the survey.

There are several facts worth noticing at this point.

The mean answer to the question concerning life satisfaction (7.3) seems consistent with other findings regarding happiness in the Czech 


\section{Ekonomie}

\section{Tab. 2: Summary statistics}

\begin{tabular}{|c|c|c|c|c|c|c|c|c|c|c|c|c|c|}
\hline Variable & Mean & Med & Min & Max & SD & $\begin{array}{l}\text { Pearson } \\
\text { Correlation } \\
\text { w/LifeSat }\end{array}$ & Variable & Mean & Med & Min & $\operatorname{Max}$ & SD & $\begin{array}{l}\text { Pearson } \\
\text { Correlation } \\
\text { w/LifeSat }\end{array}$ \\
\hline LifeSat & 7.33 & 8 & 0 & 10 & 1.78 & 1.000 & Finance & 2.02 & 3 & -5 & 5 & 2.56 & 0.273 \\
\hline Mood & 6.43 & 7 & 0 & 10 & 2.38 & 0.416 & Allowance & 957.03 & 500 & 0 & 20000 & 1381.44 & 0.033 \\
\hline MatLifeSat & 7.55 & 8 & 0 & 10 & 1.82 & 0.416 & Earnings & 1525.44 & 400 & 0 & 20000 & 2826.44 & 0.005 \\
\hline EmoLifeSat & 6.88 & 7 & 0 & 10 & 2.29 & 0.494 & OwnBusiness & 0.04 & 0 & 0 & 1 & 0.21 & 0.025 \\
\hline HappyHousing & 0.01 & 0 & 0 & 1 & 0.09 & -0.003 & ParentsBusiness & 0.35 & 0 & 0 & 1 & 0.48 & 0.037 \\
\hline HappyMoney & 0.14 & 0 & 0 & 1 & 0.34 & -0.067 & Grades & 3.25 & 3 & 1 & 5 & 0.8 & -0.084 \\
\hline HappyGrades & 0.03 & 0 & 0 & 1 & 0.18 & -0.057 & Partner & 0.47 & 0 & 0 & 1 & 0.5 & 0.024 \\
\hline HappyParents & 0.17 & 0 & 0 & 1 & 0.38 & 0.090 & RelParents & 3.36 & 4 & -5 & 5 & 2.2 & 0.304 \\
\hline HappyFriends & 0.07 & 0 & 0 & 1 & 0.26 & -0.035 & RelNationality & 7.24 & 8 & 0 & 10 & 2.46 & 0.230 \\
\hline HappyPartner & 0.18 & 0 & 0 & 1 & 0.39 & -0.053 & Entrepreneur & 5.2 & 5 & 1 & 10 & 2.78 & 0.043 \\
\hline HappyHealth & 0.21 & 0 & 0 & 1 & 0.41 & 0.060 & Selfcare & 8.35 & 9 & 0 & 10 & 1.76 & 0.231 \\
\hline HappyLeisure & 0.12 & 0 & 0 & 1 & 0.32 & 0.009 & LifeControl & 6.88 & 7 & 0 & 10 & 2.24 & 0.156 \\
\hline HappyOthers & 0.07 & 0 & 0 & 1 & 0.25 & 0.002 & FeelUnsafe & 3.87 & 3 & 1 & 10 & 2.52 & -0.218 \\
\hline Population & 22709.2 & 13000 & 1 & 100000 & 26312.9 & 0.022 & FeelUnfree & 3.93 & 3 & 1 & 10 & 2.76 & -0.197 \\
\hline Homeowner & 0.61 & 1 & 0 & 1 & 0.49 & 0.052 & Religious & 2.56 & 1 & 1 & 10 & 2.7 & -0.012 \\
\hline CommuteTime & 27.43 & 20 & 0 & 120 & 20.63 & -0.129 & Beauty & 6.9 & 7 & 1 & 10 & 2.4 & 0.072 \\
\hline LiveWParents & 0.93 & 1 & 0 & 1 & 0.26 & 0.005 & Gifts & 3651.51 & 2500 & 0 & 30000 & 3620.16 & 0.034 \\
\hline PHealth & 8.1 & 9 & 1 & 10 & 2.24 & 0.260 & Helping & 7.75 & 8 & 1 & 10 & 2.19 & 0.116 \\
\hline Mhealth & 8.01 & 9 & 1 & 10 & 2.39 & 0.313 & Needed & 6.2 & 6 & 1 & 10 & 2.43 & 0.264 \\
\hline Cigarettes & 2.21 & 0 & 0 & 30 & 4.75 & -0.108 & Nature & 7.06 & 7 & 1 & 10 & 2.51 & 0.011 \\
\hline Cannabis & 0.22 & 0 & 0 & 1 & 0.41 & -0.039 & Recycle & 0.61 & 1 & 0 & 1 & 0.49 & 0.054 \\
\hline Alcohol & 2.1 & 0 & 0 & 30 & 4.4 & -0.006 & Serious & 2.77 & 1 & 1 & 10 & 2.58 & -0.038 \\
\hline Breakfast & 5.36 & 5 & 1 & 10 & 3.61 & 0.101 & Indecisive & 5.99 & 6 & 1 & 10 & 2.78 & -0.088 \\
\hline Vegetarian & 0.05 & 0 & 0 & 1 & 0.21 & -0.045 & Attractive & 5.78 & 6 & 1 & 10 & 2.64 & 0.189 \\
\hline Vegan & 0.01 & 0 & 0 & 1 & 0.09 & 0.020 & MeaningfulLife & 7.81 & 8 & 1 & 10 & 2.43 & 0.420 \\
\hline Sport & 6.41 & 5 & 0 & 50 & 6.49 & 0.089 & SelfSatisfaction & 7.19 & 8 & 1 & 10 & 2.61 & 0.406 \\
\hline TV & 7.63 & 5 & 0 & 50 & 8.99 & -0.041 & SelfReward & 0.58 & 1 & 0 & 1 & 0.49 & 0.079 \\
\hline Friends & 14.77 & 10 & 0 & 70 & 15.12 & 0.051 & OpenToChange & 7.27 & 8 & 1 & 10 & 2.48 & 0.137 \\
\hline SocialMedia & 24.92 & 14 & 0 & 100 & 28.41 & -0.068 & Discriminated & 2.07 & 1 & 1 & 10 & 2.19 & -0.155 \\
\hline Reading & 4.21 & 2 & 0 & 50 & 7.27 & -0.064 & Gender & 0.53 & 1 & 0 & 1 & 0.5 & -0.033 \\
\hline Art & 2.93 & 1 & 0 & 50 & 6 & -0.068 & Age & 17.32 & 17 & 15 & 30 & 1.35 & 0.114 \\
\hline
\end{tabular}

Source: own

Republic. In the World Happiness Report 2015 (Helliwell et al., 2015) conducted for the United Nations the mean value reported by Czechs was 6.51. Given that reported happiness generally tends to decrease with age in Eastern European countries (Deaton, 2008) and the fact that our sample is populated with respondents of below the average age of the Czech Republic, a mean value of around 7 is not an unexpected result. Similarly, the Eurobarometer study asks "On the whole are you very satisfied, fairly satisfied, not very satisfied or not at all satisfied with the life you lead?", and the percentage values for each respective category for the Czech Republic are $17 \%, 69 \%, 12 \%$ and $1 \%$ (European Commission, 2017). Although the comparison with a $0-10$ scale is not straightforward, we can say that in both surveys most respondents are more or less satisfied with their quality of life.

Looking at the mean responses, the median student in the sample is a 17-year-old, living with her parents, with whom she gets along 
great, in their own house some 20 minutes from school. She does not smoke, nor does she drink, and her out-of-school activities are dominated by social media and hanging out with friends, but doing some sports as well and even reserving at least 1 hour per week for arts. She lives on modest income, has a great relationship to parents, confident in her ability to take care of herself in the future, and not feeling discriminated or particularly unsafe or unfree. She is an atheist, but willing to help others, considering herself as easygoing, open to change and not particularly attractive. and fairly open to change. Overall, she is satisfied with her life and considers it meaningful.

Many of the variables are well correlated with our dependent variable (see the last column in Tab. 2), but none of them too strongly, which is in some cases rather surprising. Mutual (in)dependence of selected regressors can be found in the correlation matrix (Due to the large scale, correlation coefficients and model estimates are not enclosed in this article. Appendices - Tabs. 4 a 5 can be found at the following address: http://bit.ly/JS_EM.

\section{Models}

In order to determine which factors are associated with students' level of life satisfaction, we construct a host of different models, typically in two versions. Given the discrete ordinal nature of the dependent variable, we first choose an ordered logistic regression model (OLogit). Second, we run the same specification through a plain ordinary least squares model (OLS), which, while strictly speaking less (or in-) appropriate, trumps the OLogit in its straightforward interpretation. (With a higher number of ordered classes, OLS regression tends to be is a good approximation of logit (e.g. Ferrer-i-Carbonell \& Frijters, 2004). This is, after all, what come out of our parallel logit and OLS models.)

A common problem in happiness research is the endogeneity of some regressors. An inverse causation has been found and proven for many factors that influence well-being, such as marriage (Stutzer \& Frey, 2006; Mastekaasa, 1992) or to marriage effects (social causation. While marriage as such does not appear among our variables (as mostly irrelevant for high school students), there are other variables we use where inverse causation cannot be ruled out (partner, relationship with parents, health etc.). In such cases, the prerequisites for the regression model would not be met and the model would be, strictly speaking, incorrect. However, it has been shown that even in this case regression models serve as a good approximation and that many theoretical difficulties do not cause significant deviations and distortions on a practical level (Kahneman, 1999). We therefore do not control for the endogeneity problem in any way.

In investigating the effects of different variables, we start by building separate models within each group of factors, although always controlling for gender, age and the particular school surveyed students attend (models 1 through 8). We then make use of all variables that proved in some sense relevant (significant or important) to produce combined models (9) that illustrate to what extent such variables remain relevant if put alongside other factors as well (The first category of factors (Happiness factors) was ignored in the rest of the models as it (unlike the others) comprised of certain metafactors permeating other groups.). We then proceed to models derived through including all available variables and subsequent stepwise elimination of insignificant factors while still using the same set of control variables (10). Lastly, we build an intuitive model (11) based on variables that we believed offer a straightforward link to life satisfaction and sensible interpretation.

In all instances, we tried various transformations of variables (where appropriate) to check for possible non-linear relationships. Namely, we attempted the square root transformation of variables to allow for their diminishing effects (applicable particularly to factors that appear to have a positive effect on life satisfaction), their square terms to allow for their increasing effects (applicable to presumed negative aspects of life), or tried their second order polynomial to allow for non-monotonous effects. We would choose among these alternatives according to effect on the quality of the model.

Below we present all the models of LifeSat determination, including their standard statistical properties (see Tab. 3). We defer the discussion of the important findings to section 4 .

\section{Results}

The factors lumped up in the first group labeled "Happiness factors" are all close to (similar, or 
constituent of) the dependent variable itself. This is true particularly about the first triad of variables (Mood, MatLifeSat and EmoLifeSat) that is unsurprisingly significant and important as far as their effect on LifeSat is concerned. And yet they do not correlate too closely with it, and their magnitudes suggest that students may tend to carry some of their immediate feelings (Mood) into their long-term life satisfaction assessment, and that it is what students consider an emotional component of their life satisfaction (EmoLifeSat) that matters more than material considerations (MatLifeSat). Regarding the set of dummies focused on the single most important factor students associate

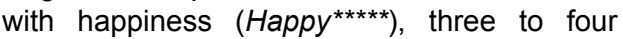
of these factors seem to stand out: grades, money and relationship to friends/parents, and in that order. In all versions and specifications of these models, HappyGrades has always the most negative effect on LifeSat: over a half of a LifeSat point lower compared to a reference group of students whose single most important factor was not listed in the survey. While grades may have carried the day in the strength of the effect, it has to be pointed out that only a small group or respondents felt this way: only about $3 \%$ (the second least frequent group after HappyHousing). This suggests it is not very widespread, but once it is the case, it drags rather heavily on students' life satisfaction, which in turn does provide some support for the notion that grades remain a substantial source of students' concern and stress.

Money-the quintessentially materialistic factor-was indicated as the most important factor by almost $14 \%$ students, who reported their LifeSat some . 3 to .4 lower compared to the reference group. Relationships to friends and parents seldom reach the standard significance levels, but they are not typically too far, and, in comparison to each other, they represent an interesting contrast. While those, who consider friends to be their number one factor $(7 \%)$, have their LifeSat almost .3 of a point lower, students cherishing good relationship with parents (almost $17 \%$ ) report on average more than 3 of a point higher LifeSat. In fact, in comparison to all other factors (listed or unlisted), the average LifeSat conditional on HappyParents to be 1 is the highest (almost a whole LifeSat point higher than for HappyGrades=1). One interpretation might be that relationship to parents is akin to a luxury good: something people care more about only after their other concerns have been taken care of, i.e. at higher levels of life satisfaction. Indeed, this interpretation would render the pyramid of needs to be grades, money, friends and parents (with position of other factors unclear), which seems not too farfetched for a teenager student. Unfortunately, such interpretation, taking these variables to indicate what students miss most, does not tally with other facts. In fact, it seems that students, if anything, tend to associate happiness with a factor, in which they are relatively rich, not poor, in comparison to the rest. Students associating happiness with grades (HappyGrades $=1$ ) are not those who have worse grades (Grades) than others (HappyGrades $=0$ ); students who suggested friends as most important factor (HappyFriends=1) are not those spend least time around friends (Friends), or students who indicated health in this regard (HappyHealth=1) are not those who exhibit worse health condition than others (PHealth or MHealth). Moreover, students who chose relations with parents (HappyParents 1 ) were actually those, who enjoy by far the best relations with parents (RelParents), and HappyPartner-positive students are actually those who are more likely to have a partner (as measured by Partner). And the same story could be told for money (as measured by Allowance or Earnings, but not the subjective assessment of financial situation - Finance).

Next we move to a discussion of the housing factors. Of all variables, the most consistently significant and important are the population size of the place of residence (Population) and the time distance to school (CommuteTime). (These two variables are not too unrelated as schools tend to operate in populated places, so generally the more populous the place of residence, the shorter the commute. This is reflected in their correlation coefficient being -0.19 .) The population seems to have a positive but waning effect, and in some specifications (model 5 and beyond), this effect may become negative beyond the population size of about 40 thousand. The effects magnitude is rather modest: e.g., moving from a place with population of 900 to a place with population of 40,000 would be associated with an increase in LifeSat ranging between 0.1 and 0.3. Or, moving from the smallest place to the largest place in the sample would only increase the LifeSat by about 0.2. 
The effect of commuting time, on the other hand, is estimated to be negative right off the start and in some specifications progressively so (models 5 and 11). Its magnitude appears relatively substantial in the separate models (4 and 5), but sinks to about a half of it in further, more refined models (9-11). So, a conservative estimate of the effect of a onestandard-deviation increase in CommuteTime from the mean value (27 minutes) would range between -0.068 and -0.012 . This is remarkably comparable to the effect of -0.064 identified by Stutzer and Frey $(2008$, p. 13) in their survey among adult population in Germany. There is another remarkable fact about the comparison: the distribution of commuting time in those two samples are very much alike despite the different socioeconomic background (adults commuting to work vs. Students commuting to school) and even time of the survey (panel $1985-1998$ vs. 2017). The means were 22.58 and 27.4 , respectively, medians both 20 , and standard deviations were 19.16 and 20.63, respectively.

The effect of being a homeowner looms large in all the separate models (a significant positive effect of almost a quarter of a point), but in presence of other factors in later models it loses its significance and importance to just about 0.1 . Living with one's parents, on the other hand, presents an opposite story: in separation, there seems to be persistently no effect at all, but in the final, intuitive model, the LivingWParents makes it close to acceptable levels of significance, and its magnitude rises to a negative quarter of a LifeSat point.

Proceeding to health and lifestyle considerations, the expectedly dominating positive effects come from the health factors. Comparing the subjective physical and mental health assessment, all models suggest a markedly stronger (up to twice as strong) association of mental health with life satisfaction. While the positive nature of the coefficients is a rather obvious result which corresponds with both common sense and positive psychology (Deci \& Ryan, 2000), the absolute magnitude of the effect does not appear to be very substantial in the light of the lip service people typically pay to its overriding importance. The difference between a completely healthy person (10) and a very unhealthy person (0) would most likely hover around 1 LifeSat points (and never exceed 2), which is generally almost comparable to relationships to parents (RelParents), or feeling needed (Needed). On the other hand, it is actually much stronger than the effects identified in other studies with adolescents: Lambert et al. (2014, p. 107-108) report a fairly comparable difference between a healthy person and one with a long term condition in happiness score (1.26 to 1.78), but measured by $\mathrm{WHO}-5$ metric on a $0-25$ scale, which means their effects of health quality are at least 2.5 times smaller, but more realistically even more (due to only a 3-point health scale they use).

A fascinating insight relates to different effects of substances students (mostly illegally) use. Cigarettes show throughout all models an amazingly consistent and significant negative effect: each cigarette per day is linked with about 0.03 decrease in LifeSat. The other usual suspect, alcohol, remains stubbornly insignificant, but consistently estimated in all models, so that it, if anything, tends to raise the LifeSat, as if approximately three units of alcohol per day could neutralize the effect of a cigarette. Even more surprisingly, though in early models only close to statistically significant, students who report being users of cannabis also report a substantially higher LifeSat by about a quarter of a point. Thus, the bottom line appears to be that of the three substances, none of which is really healthenhancing, only smoking associates with lower life satisfaction, while cannabis covaries with higher life satisfaction. (The Cannabispositive students smoke dramatically more cigarettes, so technically speaking Cigarettes and Cannabis correlate positively and very closely ( $r=0.5)$, and yet their effects on LifeSat, when controlled for other varibales, diverge.) Similarly surprising is the comparison of diet habits dummies. In all models, the effect of being a vegetarian is unclear (insignificant), but if does anything, vegetarians do enjoy lower life satisfaction. However, full vegans assess their life satisfaction by as much as a full point higher than the reference group of omnivores.

Further, there is a host of activities possibly related to life satisfaction. Time spent watching television and time spent with friends seem similarly powerful and significant, although in opposite direction. An extra hour of TV tends to decrease LifeSat just about as much as an extra hour spent with friends tends to increase it. The latter finding on importance of friends is 
fully consistent with the bottom line from models 1 discussed above. Regarding other students' activities, the situation is more complicated if the effects appear not to be linear or even monotonous. The time spent on sports, for example, is positively and significantly linked to LifeSat, although the effect is weakening as Sport rises and some specifications (models 6 and 9 ) suggest that too much of it starts to hurt: beyond about 20 hours per week, the sport becomes a drag on satisfaction. Yet, it can contribute to LifeSat by about a half of a point. Along the same lines, though not significant, the reading seems to exert a positive effect only up to (again) 20 hours per week. Its positive effect to that threshold will not exceed 0.2 of a LifeSat point. On the other hand, SocialMedia and Art both seem to start off as negative, but that effect weakens, and at one point (50 hours for SocialMedia and 23 hours for Art), both become positively related to satisfaction. Both are statistically significant, but their (negative) effects do not exceed 0.3 of a LifeSat point.

It is perhaps worth contrasting the Sport and Art variables as both together fill most of traditional extracurricular, "after-school" activities, and speculating about the explanation of the inverted shape of the effects of these variables. The hypothesis may be that it has something to do with how voluntarily students engage in these activities. For most children sport is fun, while art (e.g. piano lessons) is pain, and parents have typically harder times talking their children into doing arts than to make them do sports. This explains the initial signs of the effects. However, children who do a lot of sport may be those who are pressed by parents to become professional (and hence resentful), while children who engage in art a lot are only those who actually like it.

Discussing the role of the economic factors can be brief as out of the smaller number of variables to start with only one turns out to be both significant and substantial, and that is the subjective assessment of students' financial situation. This is, much like the importance of friends, again consistent with results of models 1. As important as we suspected the actual amounts of money students receive to be, only Earnings was not that far from being significant, but quite counterintuitively negative in its impact.

Turning now to the last but most numerous category of factors, the personal traits.
While we have seen students recognizing their grades as of importance for their life satisfaction (HappyGrades, models 1-3), the level of academic achievement (Grades) is not persuasively related to LifeSat, although the relationship appears to be positive. There is no effect of having a steady partner in the separate models, only in model 11 it comes out as both significant and having somewhat important positive impact (0.15).

Relations to parents and one's nationality both turned out in all models as significant and positive, and it is worth noting that relations to parents always trump the relations to one's nationality in their magnitude. In the final model, it is more than twice as powerful $(0.12$ vs. 0.06). Interpreting the effects of Entrepreneur, Selfcare and LifeControl, all seemingly related, is somewhat puzzling: while students' entrepreneurship associates significantly and modestly with lower LifeSat (around 0.03 LifeSat point for each Entrepreneurship point), a belief to be able to take care of oneself comes out as super-significant and 2-3 times stronger in the opposite, i.e. positive, direction, and the feeling of having one's life under one's control does not seem to matter much or at all (it is positive, but 3 times weaker and insignificant). Feeling unsafe and unfree are both significant and understandably negative in their impact on LifeSat, their magnitudes suggesting safety to be (on the margin) about twice as important as freedom for life satisfaction.

Another serious of related factors whose effects seem to lack some consistency starts with statistically significant Religious and the feeling of being needed by others (Needed), both of which are somewhat incongruous with the insignificant (and negative) willingness to help others (Helping). Furthermore, the almost significant and negative effect of being in touch with nature (Nature) is not easy to square with somewhat less significant, but much stronger and positive effect of being engaged in recycling (Recycle). And as if this was not enough, while being Indecisive seems to affect LifeSat in an understandably negative fashion (based on model 8a), why does inability to take it easy (Serious) appear to increase LifeSat (and by a greater amount)? To finish on a more intuitive note for a change, both MeaningfulLife and SelfSatisfaction are very significant, identical in direction and similar their magnitude. 


\section{Comparison with Other Studies}

After analyzing the results of our research, we briefly compare them with results of other studies that investigated factors of students' happiness. Some of the studies were conducted among university students. As students in most countries (including countries in which the studies were conducted) go to university earlier than students in the Czech Republic, the results are comparable to our survey. We included studies conducted in different countries and cultures so that we can deduce general trends present among students regardless of their origin. Tab. 3 presents a summary of such comparative endeavor.

\begin{tabular}{|c|c|c|}
\hline $\begin{array}{l}\text { Country; } \\
\text { author(s) }\end{array}$ & Positive effect on satisfaction & Negative effect on satisfaction \\
\hline $\begin{array}{l}\text { India; } \\
\text { Peltzer \& Pengpid (2013) }\end{array}$ & $\begin{array}{ll}\text { - } & \text { better social support } \\
\text { - } & \text { better personal mastery } \\
\text { - } & \text { eating breakfast daily or } \\
& \text { almost daily }\end{array}$ & - tobacco use \\
\hline $\begin{array}{l}\text { Iran; } \\
\text { Zarei (2013) }\end{array}$ & $\begin{array}{ll}\text { - } & \text { attending cultural activities } \\
\text { - } & \text { athletic experiences } \\
\text { - } & \text { religious and artistic activities } \\
\end{array}$ & \\
\hline $\begin{array}{l}\text { Iran; } \\
\text { Abedini \& Majareh (2015) }\end{array}$ & \begin{tabular}{|l|} 
- good lifestyle \\
- health
\end{tabular} & \\
\hline $\begin{array}{l}\text { New Zealand; } \\
\text { Lambert et al. (2014) }\end{array}$ & $\begin{array}{l}\text { - } \text { good connections with } \\
\text { family, friends and school } \\
\text { - } \quad \text { regular exercise } \\
\text { - } \text { meals with family }\end{array}$ & $\begin{array}{ll}\text { - } & \text { witnessing yelling and hitting } \\
& \text { of children and adults at } \\
& \text { home } \\
\text { - } & \text { discrimination } \\
\text { - } & \text { frequent marijuana use } \\
\text { - } & \text { frequal abuse } \\
\text { - } & \text { having a long-term health } \\
& \text { condition }\end{array}$ \\
\hline $\begin{array}{l}\text { Turkey; } \\
\text { Demirbatir (2015) }\end{array}$ & - educational satisfaction & $\begin{array}{ll}\text { - } & \text { stress } \\
\text { - } & \text { anxiety }\end{array}$ \\
\hline $\begin{array}{l}\text { USA; } \\
\text { Flynn \& Macleod (2015) }\end{array}$ & $\begin{array}{ll}\text { - } & \text { self-esteem } \\
\text { - } & \text { academic success } \\
& \text { financial security }\end{array}$ & \\
\hline $\begin{array}{l}\text { USA; } \\
\text { Harmening \& Jacob (2015) }\end{array}$ & $\begin{array}{ll}\text { - } & \text { being involved in social life } \\
\text { - } & \text { being included in } \\
\text { - } & \text { a community } \\
\text { good environment for living }\end{array}$ & \\
\hline $\begin{array}{l}\text { Chile; } \\
\text { Morales et al. (2015) }\end{array}$ & $\begin{array}{l}\text { - } \text { good food and good eating } \\
\text { - } \quad \text { gabits } \\
\text { - } \quad \text { good relationships with family } \\
\text { golationships with friends }\end{array}$ & \\
\hline $\begin{array}{l}\text { Czech Republic; } \\
\text { this study }\end{array}$ & $\begin{array}{ll}\text { - } & \text { good relationship with } \\
\text { parents and friends } \\
\text { - } & \text { financial situation } \\
\text { - } & \text { good mental and physical } \\
& \text { health }\end{array}$ & $\begin{array}{ll}\text { - } & \text { commuting } \\
\text { - } & \text { smoking cigarettes }\end{array}$ \\
\hline
\end{tabular}


The studies do not have a large number of overlapping variables that would enable a clean comparison across nations. However, there are three obvious commonalities that deserve being pointed out:

a) good relationships with family appear explicitly in 4 of the 9 studies (Lambert et al., 2014; Peltzer \& Pengpid, 2013; Morales et al., 2015; this study), and one can certainly read social ties into conclusions of Zarei (2013), e.g. in satisfaction with leisure time;

b) good relationships with friends appear explicitly in 5 of the 9 studies (Harmening \& Jacob, 2015; Lambert et al., 2014; Peltzer \& Pengpid, 2013; Morales et al., 2015; this study); good relationships with friends as a positive effect on happiness is also implicitly present in both studies from Iran (Abedini \& Majareh, 2015; Zarei, 2013);

c) good mental and physical health appears explicitly in only 3 of the studies (Abedini \& Majareh, 2015; Lambert et al., 2014; this study), but again some conclusions of the other studies are likely to be correlates of health (eating breakfast, normal sleep duration, athletic experience) as well.

On the other hand, international comparisons reveal some notable differences as well. For example Dogan (2016) conducted a research among 459 students high school in Bolu district of Turkey. The aim of the study was to find how usage of social networks affects the life satisfaction of high school students. The results report that the effect is positive, unlike our results that are more mixed, but support the idea that social media is not outright detrimental. Our results also did corroborate the existence of benefits of having a regular breakfast (cf. Peltzer \& Pengpid, 2013), the positive effects of academic success (cf. Flynn \& Macleod, 2015) or negative effects of alcohol or marijuana use (cf. Lambert et al., 2014).

\section{Conclusions}

In this study, we selected a specific social group, namely a total of 1,414 high school students from 11 different schools in the northern region of Czech Republic, which we surveyed in order to identify what aspects of their life make a difference to their life satisfaction, in which direction and how much. Data gathered through questionnaires was analyzed in a series of OLogit and OLS models.

Some findings of our study confirm the expected (and the well-established in many other studies): positive effects of one's relations to parents and friends, or one's health conditions, and negative effects of smoking tobacco or being discriminated. The relatively unestablished findings would include the positive effect of being needed, or the negative effect of commuting time. The outright surprising results include the seeming irrelevance of alcohol consumption (contrary to expected negative effects) or the absolute amount of money available (contrary to expected positive effects); the positive effect of cannabis use, of being a vegan; or the partially negative effect of engaging in arts or creative activities.

The ultimate objective of understanding utility functions is arguably not to satisfy social scientists' curiosity, but to help people-simply put-live better. This is the common theme of both high flown government policies addressing education or health care, and day-to-day parental practices addressing good manners, and is instrumental ultimately to the objects of the research themselves. After all, authors from philosophers to pundits have for a long time attempted to create recipe-like to-do or not-todo lists for people to learn from or live by (e.g. Holmes, Kleiner, Douglas, \& Bond, 2003).

Our study can serve as a small contribution to this endevour by (yet again) confirming importance of some factors (relationships and health) and adding credence to so far relatively neglected aspects of life (commuting). One has to constantly bear in mind the thorny complexity of causality: very few finding are directly malleable to a life-style recommendation. For example, our study may point to veganism as to a significant predictor of life satisfaction, but students would most likely be ill-advised to become vegans, and expect to become happier in consequence. Similarly, it would be wrong to interpret some counterintuitive results of our study, e.g. the positive effects of cannabis consumption, as disproving the intuition, but they may serve as a warning that some intuitive conclusions of other studies might be premature and/or environment-specific. Further, turning some findings of happiness research into advices would be downright trivial: e.g. being healthy is hardly an eye-opening advice for most people. On the other hand, factors like commuting or quality of relations and their effects on life satisfaction may emphasize something that escapes attention of people's introspection in ordinary lives. 
Results of our study are of course limited by a lack of representativeness. The recommendation for further research will therefore not deviate from the traditional call for replication elsewhere.

The authors would like to gratefully acknowledge a financial support by an internal grant at Purkyně University, Ústí nad Labem, Czech Republic.

\section{References}

Abedini, M., \& Majareh, S. A. (2015). Study of Relationships among Lifestyle, Health Locus of Control, and Happiness in Students. Basic \& Clinical Cancer Research, 7(4), 9-17.

Becchetti, L., Castriota, S., \& Tortia, E. C. (2013). Productivity, wages and intrinsic motivations. Small Business Economics, 41(2), 379-399. https://doi.org/10.1007/s11187-0129431-2.

Bissell, G. (Ed.). (2012). Motivation: what makes social work a good job? In Organisational behaviour for social work (pp. 21-38). Policy Press at the University of Bristol. https://doi. org/10.2307/j.ctt1t891zp.7.

Broedling, L. A. (1977). The Uses of the Intrinsic-Extrinsic Distinction in Explaining Motivation and Organizational Behavior. The Academy of Management Review, 2(2), 267-276. https://doi.org/10.2307/257908.

Bruni, L., \& Porta, P. L. (Eds.). (2007). Handbook on the Economics of Happiness. Edward Elgar Publishing. https://doi. org/10.4337/9781847204158.

Case, A., \& Deaton, A. (2016). Suicide, Age, and Wellbeing: an Empirical Investigation. In D. A. Wise (Ed.), Insights in the Economics of Aging. University of Chicago Press.

Cattaneo, M. D., Galiani, S., Gertler, P. J., Martinez, S., \& Titiunik, R. (2009). Housing, health, and happiness. American Economic Journal: Economic Policy, 1(1), 75-105. https:// doi.org/10.1257/pol.1.1.75.

Coombs, R. H. (1991). Marital Status and Personal Well-Being: A Literature Review. Family Relations, 40(1), 97-102. https://doi. org/10.2307/585665.

Curran, J. (2018). Mindfulness, Sustainability, and the Power of Personal Practice. In Narratives of Educating for Sustainability in Unsustainable Environments (pp. 181-200). Michigan State University Press.
Deaton, A. (2008). Income, health, and well-being around the world: Evidence from the Gallup World Poll. The Journal of Economic Perspectives, 22(2), 53-72. https://doi. org/10.1257/jep.22.2.53.

Deci, E. L., \& Ryan, R. M. (2000). The "What" and "Why" of Goal Pursuits: Human Needs and the Self-Determination of Behavior. Psychological Inquiry, 11(4), 227-268. https://doi.org/10.1207/S15327965PLI1104_01.

Delfgaauw, J., \& Dur, R. (2008). Incentives and Workers' Motivation in the Public Sector. The Economic Journal, 118(525), 171-191. https://doi.org/10.1111/j.1468-0297.2007.02108.x.

Demirbatir, R. E. (2015). Relationships between Psychological Well-Being, Happiness, and Educational Satisfaction in a Group of University Music Students. Educational Research and Reviews, 10(15), 2198-2206. https://doi.org/10.5897/ERR2015.2375.

Diener, E., \& Chan, M. Y. (2011). Happy People Live Longer: Subjective WellBeing Contributes to Health and Longevity. Applied Psychology: Health and Well-Being, 3(1), 1-43. https://doi.org/10.1111/j.17580854.2010.01045.x.

Diener, E., Gohm, C. L., Suh, E., \& Oishi, S. (2000). Similarity of the relations between marital status and subjective well-being across cultures. Journal of Cross-Cultural Psychology, 31(4), 419-436. https://doi.org/10.1177/002202 2100031004001.

Diener, E., \& Seligman, M. E. P. (2004). Beyond Money: Toward an Economy of WellBeing. Psychological Science in the Public Interest, 5(1), 1-31. https://doi.org/10.1111/ j.0963-7214.2004.00501001.x.

Dogan, U. (2016). Effects of social network use on happiness, psychological well-being, and life satisfaction of high school students: Case of facebook and twitter. Egitim ve Bilim, 41(183), 217-231. https://doi.org/10.15390/ EB.2016.4616.

Easterlin, R. A. (1974). Does economic growth improve the human lot? Some empirical evidence. In P. David, \& M. K. Reder (Eds.), Nations and households in economic growth: Essays in Honour of Moses Abramowitz (pp. 89125). Academic Press. https://doi.org/10.1016/ B978-0-12-205050-3.50008-7.

European Commission. (2017). Eurobarometer Survey. European Commission. Retrieved from http://ec.europa.eu/commfrontoffice/publicopinion/ index.cfm/Chart/getChart/themeKy/1/groupKy/1. 
Ferrer-i-Carbonell, A., \& Frijters, P. (2004). How Important is Methodology for the Estimates of the Determinants of Happiness? The Economic Journal, 114(497), 641-659. https:// doi.org/10.1111/j.1468-0297.2004.00235.x.

Flynn, D. M., \& Macleod, S. (2015). Determinants of Happiness in Undergraduate University Students. College Student Journal, 49(3), 452-460.

Frey, B. S. (2008). Happiness: A Revolution in Economics (Munich Lectures in Economics). Cambridge: The MIT Press. https://doi.org/ 10.7551/mitpress/9780262062770.001.0001.

Gardner, J., \& Oswald, A. (2001). Does money buy happiness? A longitudinal study using data on windfalls. Unpublished manuscript. Retrieved from http://www.repec. org/res2002/Gardner.pdf.

Georgellis, Y., Iossa, E., \& Tabvuma, V. (2011). Crowding Out Intrinsic Motivation in the Public Sector. Journal of Public Administration Research and Theory: J-PART, 21(3), 473-493. https://doi.org/10.1093/jopart/muq073.

Harmening, D. S., \& Jacob, S. A. (2015). Institutional Factors That Positively Impact First-Year Students' Sense of Well-Being. Journal of Case Studies in Education, 7.

Helliwell, J. F. (2006). Well-Being, Social Capital and Public Policy: What's New? The Economic Journal, 116(510), C34-C45. https:// doi.org/10.3386/w11807.

Helliwell, J. F., Layard, R., \& Sachs, J. (2015). World happiness report 2015. New York: Sustainable Development Solutions Network.

Holder, M. D., \& Coleman, B. (2009). The Contribution of Social Relationships to Children's Happiness. Journal of Happiness Studies, 10(3), 329-349. https://doi.org/10.1007/ s10902-007-9083-0.

Holmes, B., Kleiner, K., Douglas, K., \& Bond, M. (2003, April 10). Reasons to be cheerful. New Scientist. Retrieved from https://www.newscientist.com/article/ mg18024155-200-reasons-to-be-cheerful/.

Kahneman, D. (1999). Objective Happiness. In D. Kahneman, E. Diener, \& N. Schwarz (Eds.), Well-being: Foundations of Hedonic Psychology. Russell Sage Foundation.

Kahneman, D., \& Deaton, A. (2010). High income improves evaluation of life but not emotional well-being. Proceedings of the National Academy of Sciences, 107(38), 16489-16493. https://doi.org/10.1073/ pnas. 1311600111.
Kalvans, E., \& Ignatjeva, S. (2013). Latgale Inhabitants' Satisfaction with the Quality of Social Environment Micro and Macro Factors "Family", "Job" and "State" and its Impact on Their Feeling of Happiness. Regional Review, (9), 49-63.

Kasser, T. (2002). The high price of materialism. MIT Press.

Kasser, T., \& Ryan, R. M. (2001). Be careful what you wish for: Optimal functioning and the relative attainment of intrinsic and extrinsic goals. In P. Schmuck \& K. Sheldon (Eds.), Life goals and well-being: Towards a positive psychology of human striving (pp. 116-131). Hogrefe \& Huber Publishers.

Kozma, A., \& Stones, M. J. (1983). Predictors of happiness. Journal of Gerontology, 38(5), 626-628. https://doi.org/10.1093/ geronj/38.5.626.

Lambert, M., Fleming, T., Ameratunga, S., Robinson, E., Crengle, S., Sheridan, J.,... Merry, S. (2014). Looking on the bright side: An assessment of factors associated with adolescents' happiness. Advances in Mental Health, 12(2), 101-109. https://doi.org/10.1080/ 18374905.2014.11081888.

Lambright, K. T. (2009). Agency Theory and beyond: Contracted Providers' Motivations to Properly Use Service Monitoring Tools. Journal of Public Administration Research and Theory: J-PART, 19(2), 207-227. https://doi. org/10.1093/jopart/mun009.

Levitt, S. D., List, J. A., Neckermann, S., \& Sadoff, S. (2012). The behavioralist goes to school: Leveraging behavioral economics to improve educational performance. National Bureau of Economic Research. https://doi. org/10.3386/w18165.

Lucas, R. E., Diener, E., \& Suh, E. (1996). Discriminant Validity of Well-being Measures. Journal of Personality and Social Psychology, 71(3), 616-628. https://doi.org/10.1037//00223514.71.3.616.

Madridejos-Mora, R., Amado-Guirado, E., \& Pérez-Rodríguez, M. T. (2004). Effectiveness of the Combination of Feedback and Educational Recommendations for Improving Drug Prescription in General Practice. Medical Care, 42(7), 643-648. https://doi.org/10.1097/01. mlr.0000129495.43422.58.

Mastekaasa, A. (1992). Marriage and Psychological Well-Being: Some Evidence on Selection into Marriage. Journal of Marriage and Family, 54(4), 901-911. https://doi. org/10.2307/353171. 
Morales, B. S., Calderón, L. O., Andrade, G. L., Vargas, H. M., Maldonado, J. S., Etchebarne, M. S.,... Grunert, K. G. (2015). Relationship between the domains of the Multidimensional Students' Life Satisfaction Scale, satisfaction with food-related life and happiness in university students. Nutrición Hospitalaria: Organo Oficial de La Sociedad Española de Nutrición Parenteral y Enteral, 31(6), 2752-2763. https:// doi.org/10.3305/nh.2015.31.6.8593.

Murdock, K. (2002). Intrinsic Motivation and Optimal Incentive Contracts. The RAND Journal of Economics, 33(4), 650-671. https://doi.org/10.2307/3087479.

Nettle, D. (2006). Happiness: The Science Behind Your Smile. Oxford University Press. https://doi.org/10.7861/clinmedicine.6-2-214.

Peltzer, K., \& Pengpid, S. (2013). Subjective happiness and health behavior among a sample of university students in India. Social Behavior and Personality: An International Journal, 41(6), 1045-1056. https://doi.org/10.2224/ sbp.2013.41.6.1045.

Phipps-Taylor, M., \& Shortell, S. M. (2016). More Than Money: Motivating Physician Behavior Change in Accountable Care Organizations. The Milbank Quarterly, 94(4), 832-861. https://doi.org/10.1111/14680009.12230 .

Scitovsky, T. (1976). The joyless economy: An inquiry into human satisfaction and consumer dissatisfaction. New York: Oxford University Press.

Stack, S., \& Eshleman, J. R. (1998). Marital Status and Happiness: A 17-Nation Study. Journal of Marriage and Family, 60(2), 527536. https://doi.org/10.2307/353867.

Stevenson, B., \& Wolfers, J. (2013). Subjective well-being and income: Is there any evidence of satiation? The American Economic Review, 103(3), 598-604. https://doi. org/10.1257/aer.103.3.598.

Stutzer, A., \& Frey, B. S. (2006). Does marriage make people happy, or do happy people get married? The Journal of SocioEconomics, 35(2), 326-347. https://doi. org/10.1016/j.socec.2005.11.043.

Stutzer, A., \& Frey, B. S. (2008). Stress that doesn't pay: The commuting paradox. The Scandinavian Journal of Economics, 110(2), 339-366. https://doi.org/10.1111 /j.1467-9442.2008.00542.xc.

Uchida, Y., Norasakkunkit, V., \& Kitayama, S. (2004). Cultural Constructions of Happiness: Theory and Emprical Evidence. Journal of Happiness Studies, 5(3), 223-239. https://doi. org/10.1007/s10902-004-8785-9.

van Schie, S., Güntert, S. T., \& Wehner, T. (2014). How Dare to Demand This from Volunteers! The Impact of Illegitimate Tasks. Voluntas: International Journal of Voluntary and Nonprofit Organizations, 25(4), 851-868. https://doi.org/10.1007/s11266-013-9375-4.

Zarei, S. (2013). Investigating the Factors Having Influence on the Student's Happiness: A Survey Between Students of Secondary Schools of Shiraz. Romanian Review of Social Sciences, (4).

\section{Julius Janáček}

J. E. Purkyně University in Ústí nad Labem Faculty of Social and Economic Studies Department of Economics and Management Czech Republic juliusjanacek@post.cz

\section{Dan Št'astný}

J. E. Purkyně University in Ústí nad Labem Faculty of Social and Economic Studies Department of Economics and Management

Czech Republic daniel.stastny@ujep.cz and University of New York in Prague School of Business Czech Republic 


\section{Abstract}

\section{INQUIRY INTO HIGH SCHOOL STUDENTS' UTILITY FUNCTION Julius Janáček, Dan Štastný}

This study uses data from our life-satisfaction survey of 1,414 students in 11 high schools in Northern parts of Czech Republic in the spring 2017 to discover certain parts of high school students" utility function. This is potentially useful for audiences ranging from macro-level policy-makers to teachers to parents to the students themselves in improving the design of policies and practices that either address life-satisfaction directly or affect it indirectly by pursuing other objectives. We use ordered logit and OLS regression models in various specifications to explore how different factors of students' life from various domains (e.g. housing, economic, lifestyle, personal) associate with their self-assessed degree (0-10 scale) of life satisfaction or happiness. The effects of independent variables were investigated both separately within their own domain, and in all-inclusive models while always controlling for gender, age and specific effects of particular schools. The results confirm quite robustly several well-established and expected effects, namely the positive effects of one's relations to parents and friends, or one's health conditions, and negative effects of smoking tobacco or being discriminated. The findings also reveal some relatively unestablished facts such as a large positive effect of being needed, or the negative effect of commuting time. The outright surprising results include the irrelevance of alcohol consumption (contrary to expected negative effects and in contrast to identified negative effects of tobacco consumption) or of the absolute amount of money available (contrary to expected positive effects); the positive effect of cannabis use and of being a vegan; or the partially negative effect of engaging in arts or creative activities. While the above results are not all easily turned into recommendations for students, their parents, school administrators or policy makers on how to secure a happy life of teenagers, there are a few that may go beyond the obvious: avoid smoking, consider commuting time seriously, encourage and nurture good relations. Caveats regarding external validity apply.

Key Words: Utility, happiness, life satisfaction, students, high school, health, relationship, commuting, substance use.

JEL Classification: I31.

DOI: 10.15240/tul/001/2018-3-004 